\title{
Heterothallic and homothallic sexual reproduction in Tabularia fasciculata (Bacillariophyta)
}

\author{
Nickolai A. Davidovich ${ }^{1 *}$, Irena KacZMArskA ${ }^{2} \&$ James M. Ehrman ${ }^{3}$ \\ ${ }^{1}$ Karadag Natural Reserve of the National Academy of Sciences, Feodosiya, 98187, Ukraine; \\ *corresponding author e-mail: nickolaid@yandex.ru; fax: +0380656226212 \\ ${ }^{2}$ Department of Biology, Mount Allison University, Sackville, New Brunswick, E4L 1G7, Canada \\ ${ }^{3}$ Digital Microscopy Facility, Mount Allison University, Sackville, New Brunswick, E4L 1G7, Canada
}

\begin{abstract}
Sexual behaviour, pattern of auxosporulation, and breeding system of the araphid diatom Tabularia fasciculata were studied using 64 clones derived from two natural populations from the Canadian Atlantic seashore and the Black Sea. Both inter- and intraclonal reproductions were observed. Heterothallic reproduction was morphologically and behaviourally heterogamous. The heterothallic nature of sexual reproduction in this species allowed the determination of sex ratio in the population, which was 1:1 male:female. A novel type of active movement of gametes designated as male was described and pathways traced and recorded. A few male clones could reproduce intraclonally, but this was not abundant compared to interclonal reproduction. The advantages and inferred significance of each mode of reproduction are discussed. In the semi-natural population of $T$. fasciculata, two size classes were detected among sexualized individuals, and they gave rise to two size groups of initial cells. Sexual compatibility of all derived clones was independent of cell size class. In cultures, the apical length of initial cells was also strongly correlated to the size of parental gametangia. Cell sizes corresponding to cardinal points in the life cycle were established. Interbreeding of clones derived from the Canadian Atlantic and the Black Sea suggests a pan-Atlantic reproductive compatibility of populations of diatoms conforming to current morphological delineation of T. fasciculata.
\end{abstract}

Key Words: breeding system, diatoms, gamete mobility, life cycle, sexual reproduction, Tabularia fasciculata

\section{Introduction}

Tabularia fasciculata (C.A. AgARdH) D.M. WiLLIAMS \& Round is one of the most widespread species of the newly erected genus Tabularia (Williams \& Round 1986). It has a wide geographic distribution and tolerance of a wide range of salinity, and has been reported from marine, brackish, and freshwater habitats (SNOeiss 1992). As well, the species is known for its considerable confusion over its identity and nomenclature; several taxa are probably involved in the Tabularia fasciculata-complex (Williams \& Round 1986). Uncertainties in the taxonomy of the genus Tabularia remain under discussion (ARChIBALD 1983; Williams \& Round 1986; Snoeiss 1992; Morales 2003; Stoermer \& ANDRESEN 2006).

The current taxonomy of diatoms is based nearly entirely on cell wall morphology and microstructure, and may not be sufficient to discriminate species with a wide range of morphological variability or in cryptic speciescomplexes with seemingly unvaried morphology. More complex approaches, including new molecular and genetic methods are proving to be helpful in separating such members of morphospecies complexes (LundHolm et al. 2003, 2006; SARNO et al. 2005). Molecular markers (SSU, ITS-region, cox1, rbcL and LSU) have been successfully used to examine variation within and between species in several genera (MANHART et al. 1995; BeHNKE et al. 2004; Lundholm et al. 2006; AMATo et al. 2007; Evans et al. 2007; KACZMARSKA et al. 2007b, 2008; Moniz \& KaCZMARSKA 2009). At the same time, for most amphimictic diatom species, sexual compatibility probably remains the single most direct way to test biological species boundaries.

Among Fragilariaceae sensu Greville (Round et al. 1990), the sexual process has been examined in several species, albeit in most 
cases more than a decade ago; Tabularia affinis (as Synedra affinis KüTZING [in KARSTEN 1899]), Diatoma elongatum (Lyngbye) C. Agardh, Meridion circulare (Greville) C. Agardh, Fragilaria crotonensis Kitton, Synedra ulna (Nitzsch) Ehrenberg, S. rumpens Grunow, $S$. amphicephala KÜTZING, S. vaucheriae (KüTZING) Kützing (reviewed by Geitler 1973), Tabularia tabulata (as Synedra tabulata) and Fragilaria delicatissima Proshrina-Lavrenko (Roshchin 1987, 1989, 1994). A cis-anisogamous sexual behaviour corresponding to GeITLER's type IA2 (GEITLER 1973) is normal for most of the cited members of Fragilariaceae; consistent with the majority of other araphid diatoms (CHEPURNOV \& Mann 2004; Chepurnov et al. 2004). Recent findings (KooIstra et al. 2009) indicate however that the family Fragilariaceae is paraphyletic, and that Tabularia may be more closely related to Thalassionemataceae than to Fragilariaceae. Much less is known about sexual reproduction and life histories of thalassionematoid compared to fragilarioid lineages.

Differentiation of clones into two mating types, or "male" and "female" wherever it is possible to determine, assumes sex to be determined diplogenotypically, but very little is known about the genetics of sex-determination in diatoms (MANN et al. 2003; DAvidovich et al. 2006). In pennates, including members of Fragilariaceae, heterothally seems to be the common form of mating (RoshCHIN 1994; MANN et al. 1999; Chepurnov \& Mann 2004; Chepurnov et al. 2004), but infrequent intraclonal reproduction of male clones was observed in T. tabulata and $F$. delicatissima (Roshchin 1994). This coexistence of two types of mating behaviour within a single sympatric population was interpreted as an alternation of monoecy and dioecy ("monoecydioecy") in consecutive generations (Roshchin 1994; Roshchin \& Chepurnov 1999). Here we suggest an alternative explanation for this type of reproductive strategy.

The goal of this study was to expand our understanding of sexual reproduction in araphid pennate diatoms, namely in the taxonomically difficult T. fasciculata-complex, using cultured and semi-natural populations from Canada and Ukraine. This paper is complementary to Kaczmarska et al. (2009) and fulfilled on the same material.

\section{Materials and methods}

Water and macroalgae were collected at Cape Tormentine, on the Gulf of St. Lawrence shore of New Brunswick, Canada on 17 January $\left(46^{\circ} 13^{\prime} 25^{\prime \prime} \mathrm{N}\right.$, $\left.63^{\circ} 78^{\prime} 10^{\prime \prime} \mathrm{W}\right)$ and 5 February $2006\left(46^{\circ} 13^{\prime} 40^{\prime \prime} \mathrm{N}\right.$, $\left.63^{\circ} 77^{\prime} 87^{\prime \prime} \mathrm{W}\right)$. An abundant T. fasciculata population was found on the surface of a disintegrating frond of the red alga Porphyra umbilicalis (L) J. AgARDH, from which clonal cultures were derived within eleven days after sampling. Usually individual cells or in some rare cases fasciculate clonal clusters of equally long cells attached by one tip to the same gelatinous pad were isolated into a monoclonal culture using micropipettes and an Olympus light microscope (LM). We initiated the monoclonal lines by targeting individual cells of different length to increase the probability of isolating different genotypes. The captured cells were discharged into a sterile rinsing droplet several times (3 to 7) and finally into wells with Guillard \& Ryther's f/2 medium (ANDERSEN et al. 2005, p. 507), or its diluted concentrations $\mathrm{f} / 4, \mathrm{f} / 10$ or $\mathrm{f} / 20$. Diluted concentrations provided more successful initial isolations, while established cultures grew better on full strength medium. One year later, on 6 February 2007, five clones of $T$. fasciculata were isolated from epilithon samples gathered at the littoral near the Karadag biological station, Crimea, Ukraine (44⒌ $\left.54^{\prime} 41^{\prime \prime} \mathrm{N}, 35^{\circ} 12^{\prime} 04^{\prime \prime} \mathrm{E}\right)$. Artificial seawater, ESAW medium (ANDERSEN et al. 2005 , p. 494) was used for clones isolated from the Black Sea.

A total of 59 monoclonal cultures of T. fasciculata were established from Canadian populations and five clones were derived from the Black Sea; the last were designated as [clone name]_Ukr. Canadian clones were maintained in well-trays containing $c .15 \mathrm{ml}$ of medium in a growth-room at $18-20{ }^{\circ} \mathrm{C}$, irradiance of 30-60 $\mu$ mol photons $\cdot \mathrm{m}^{-2} \cdot \mathrm{s}^{-1}$ and 10:14 h light:dark cycle. Crosses were performed in plastic tissue-culture plate wells under the same growth conditions.

Every 4-6 days cultures were re-inoculated into fresh medium to maintain them in exponential growth phase. Cultures were inspected daily for signs of intraclonal sexual reproduction, general health, growth, and size homogeneity using a Zeiss inverted microscope at $c$. $\times 100$ magnification. From 20 February to 3 March 2006 clones were periodically inoculated in pairs to facilitate interclonal reproduction, with 144 pairwise combinations examined (see Supplementary Table S1 and Table of mating in KaczmarsKa et al. 2009). Not all possible pairwise combinations were conducted but all clones were mated, among others, with control pair T0206-A (female) and T0206-G (male), the first pair of clones that revealed sexual reproduction in the mixture of clones. Some pairs readily entered sexual reproduction while others were inoculated two or three times before mating was observed.

Interclonal reproduction was considered to have 
occurred when: (1) it was abundant (tens of auxospores per area examined, about 3-7 $\mathrm{cm}^{2}$ ) and (2) empty thecae of both male and female gametangia were found in abundance. Different sizes of parent cells provided conclusive means to determine whether reproduction was inter- or intraclonal.

Microphotographs were taken through the ocular of the Zeiss inverted microscope with a Canon PowerShot A-95 digital camera, which was used also for recording gamete movement on the background of immobile vegetative cells and gametangia frustules. Coordinates for the two-dimensional representation of the pathway of a single gamete were measured from real-time digital image frames using Image J $1.34 \mathrm{~s}$ software (http://rsb.info.nih.gov/ij/).

For scanning electron microscopy (SEM), samples were prepared as described in KACZMARSKA et al. (2005) and examined using a JEOL JSM-5600 SEM at the Digital Microscopy Facility, Mount Allison University. At least four, but most commonly six to eight apical valve length measurements were made for parents and progeny in each clone to calculate means and standard errors (mean $\pm \mathrm{SE}$ ). Thickness of the valve mantle at the apices was measured from inside of the opened valves on SEM images. Linear regression coefficients were calculated by using the standard least-squares method. Fisher's Exact Test (http:// graphpad.com/quickcalcs/contingency1.cfm/) was applied to evaluate the significance of the association between maleness and intraclonal auxosporulation.

\section{Results}

\section{Morphology and life form}

Species habit and live cell: In the natural populations, Tabularia fasciculata grew attached, either as single cells or in clusters of cells radiating from a common mucilaginous pad exuded via an apical pore field (ocellulimbus, sensu WILLIAMS \& Round 1986). In culture, rapidly growing clones formed loose (unattached) colonies on the bottom of culture dishes (Fig. 1); rare single cells could be observed detached from the bottom and floating through the water. Fan-shaped colonies (Fig. 2) were found in some clones. Smaller cells often maintained valve-to-valve contact after cytokinesis and grew as long ribbons (Fig. 3). Sometimes, cells grew in hemispherical clusters (Fig. 4), all attached by one tip to a common mucilage pad.

The number of chloroplasts was difficult to establish because individual plastids overlap, but in some cases we counted 8-12 per cell (Figs 5, 24) and this number appeared to double before mitotic cell division.
Frustule morphology and structure: Frustules were heavily silicified, rectangular in girdle view and consisted of two valves and the cingulum including valvocopula, apparently two copulae and two smaller pleurae. Finely crenulated valvocopulae had no areolae (Fig. 6), pleurae perhaps had one (Fig. 7) and copulae had two rows of areolae (Figs 6, 8). Thickness of the valve mantle at the apices ranged between $0.2-$ $0.5 \mu \mathrm{m}$ (mean $\pm \mathrm{SE}=0.39 \pm 0.01, \mathrm{n}=39)$. Valve outlines varied from lanceolate to needle-like and were 10.3-248.0 $\mu \mathrm{m}(\mathrm{n}=1480)$ long, and 3.8-9.0 $\mu \mathrm{m}(\mathrm{n}=164)$ wide. For comparison, the apical length of cells derived from the Black Sea varied from 16.1 to $163.2 \mu \mathrm{m}(\mathrm{n}=218)$, in the smallest vegetative cells following two years of cultivation and in initial cells respectively. The striae were coarse, $10-16$ in $10 \mu \mathrm{m}$ and varied in length, leaving a very narrow or a very wide unornamented sternum (Figs 8-10). Individual striae observed from the inner side of the valve were in the form of one deep cavity with thin bottom cribra divided by $2-12$ thin longitudinal cross-bars, depending on the areola length (Fig. 10). Sometimes one (Fig. 11) but usually two (Fig. 12) rimoportulae per valve (and occasionally none in cultured cells) were located near the valve apex, varying in location in some valves of the same clone. Internally rimoportulae were oval in outline (Fig. 13), externally the process opened with a simple elongated fissure (Fig. 14). Valve tips were rounded (Fig. 13), obtuse (Fig. 14) or slightly sub-capitate (Fig. 6). A distinct pore field (ocellulimbus) was present at each valve end.

\section{Cell sizes in pre and post-sexual cells}

The apical length of 1480 cultured cells and cells from a natural Canadian population of $T$. fasciculata, including 228 gametangial and 422 initial cells was measured. In cultures, initial cells were measured in crosses of 21 different parental pairs, as well as those resulting from intraclonal reproduction of 4 clones. These measurements allow the determination of 'cardinal points' sensu Geitler (1932, 1935) and cell-size ranges for principal stages of the life history in $T$. fasciculata (Fig. 15). The apical length of our cells capable of sexual reproduction ranged from $10-113 \mu \mathrm{m}$ and the length of resulting initial cells ranged from 98-248 $\mu \mathrm{m}$.

Auxosporulation in a local semi-natural population of $T$. fasciculata from the P. umbilicalis blade was profuse (the length of 68 gametangia 
Table 1. Sex and reproductive behavior of Tabularia fasciculata clones randomly derived from the local population, as detected in mating experiments.

\begin{tabular}{|c|c|c|c|c|c|}
\hline Clone name & $\operatorname{Sex}^{1}$ & $\begin{array}{l}\text { Intraclonal } \\
\text { reproduction }{ }^{2}\end{array}$ & Clone name & Sex & $\begin{array}{l}\text { Intraclonal } \\
\text { reproduction }\end{array}$ \\
\hline Т 0206-A & $\mathrm{F}$ & - & T 0208-ABS & $\mathrm{F}$ & \\
\hline T 0206-D & F & - & T 0208-AD & M & - \\
\hline T 0206-E & $\mathrm{F}$ & - & T 0208-AE & M & - \\
\hline Т 0206-F & $\mathrm{F}$ & - & T 0208-AF & $\mathrm{F}$ & - \\
\hline Т 0206-G & M & + & T 0208-AS & (M?) & - \\
\hline Т 0206-H & F & - & Т 0208-W & F & + \\
\hline Т 0206-J & $\mathrm{F}$ & - & Т 0208-X & F & - \\
\hline Т 0206-K & M & - & Т 0214-AB & M & - \\
\hline T 0206-L & M & + & T 0214-AC & M & - \\
\hline Т 0206-M & M & - & T 0214-AH & $\mathrm{F}$ & - \\
\hline T 0206-N & F & - & T 0214-AI & M & - \\
\hline Т 0206-P & M & - & T 0214-AL & M & - \\
\hline T 0206-Q & F & - & T 0214-AM & $\mathrm{F}$ & - \\
\hline T 0206-R & $\mathrm{F}$ & - & T 0214-AO & M & - \\
\hline Т 0206-V & M & + & T 0214-AQ & M & - \\
\hline T 0206-W & M & - & T 0214-J & $\mathrm{F}$ & - \\
\hline Т 0207-Q & M & - & Т 0214-Q & M & - \\
\hline T 0207-R & F & - & T 0214-W & M & - \\
\hline Т 0207-U & M & - & Т 0214-X & $\mathrm{F}$ & - \\
\hline Т 0208-A & $\mathrm{F}$ & - & Т 0217-C & M & - \\
\hline Т $0208-A B$ & $\mathrm{~F}$ & - & Т 0217-I & M & - \\
\hline
\end{tabular}

${ }^{1} \mathrm{~F}$, female clone; M, male clone; (M?), presumably male clone in view of the ability to reproduce intraclonally and spherical ('male' type) gametes; this clone was lost before mating experiments.

+ , registered ability to reproduce intraclonaly; -, intraclonal reproduction was not detected.

and 59 initial cells was measured in a few fields of view in the microscope), and provided data for cell size-class histograms (Fig. 16). Mass auxosporulation was observed two days after a small fragment of the blade from Porphyra umbilicalis with an epiphytic population of $T$. fasciculata was placed in $\mathrm{f} / 2$ medium in the lab. Because many auxospores and initial cells remained associated with maternal thecae (Figs 24-28), it was possible to correlate sizes of gametangia and corresponding initial cells, which was positive and significant (Fig. 17, $\mathrm{R}^{2}=0.65, \mathrm{p}$ $<0.01)$.

The length of initial cells produced in crosses between clones T0206-A and T0206-G varied considerably, from 140-240 $\mu \mathrm{m}$ (Fig. 18). The coefficient of variation of the length of initial cells was $8.2 \%$, which was two times higher than in parental clones $(3.9$ and $3.6 \%$ for female and male, respectively). In cultures, the apical length of initial cells was also strongly correlated to the size of parental gametangia (Fig. 19, $\mathrm{R}^{2}=0.85, \mathrm{p}$ $<0.001)$.

\section{Sexual reproduction}

Homothallic (intraclonal) reproduction: Large cell products of intraclonal auxosporulation were first detected in clone T0208-AS, when six descendant cells were found among a single, discrete cluster of radiating empty, opened frustules (Fig. 20). Based on the presence of gametes, the expected form of auxospores, and the size of progeny cells close to the maximum observed during this study we assume that auxosporulation was sexual. The apical length of cells of the parental clone (on average $104.0 \pm 3.8 \mu \mathrm{m}, \mathrm{n}=3$ ) and of progeny $(229.8 \pm 9.2 \mu \mathrm{m}, \mathrm{n}=4)$ allowed the preliminary estimation of two cardinal points in the life history of the diatom, namely the upper threshold for sexualization and the maximal species-specific 

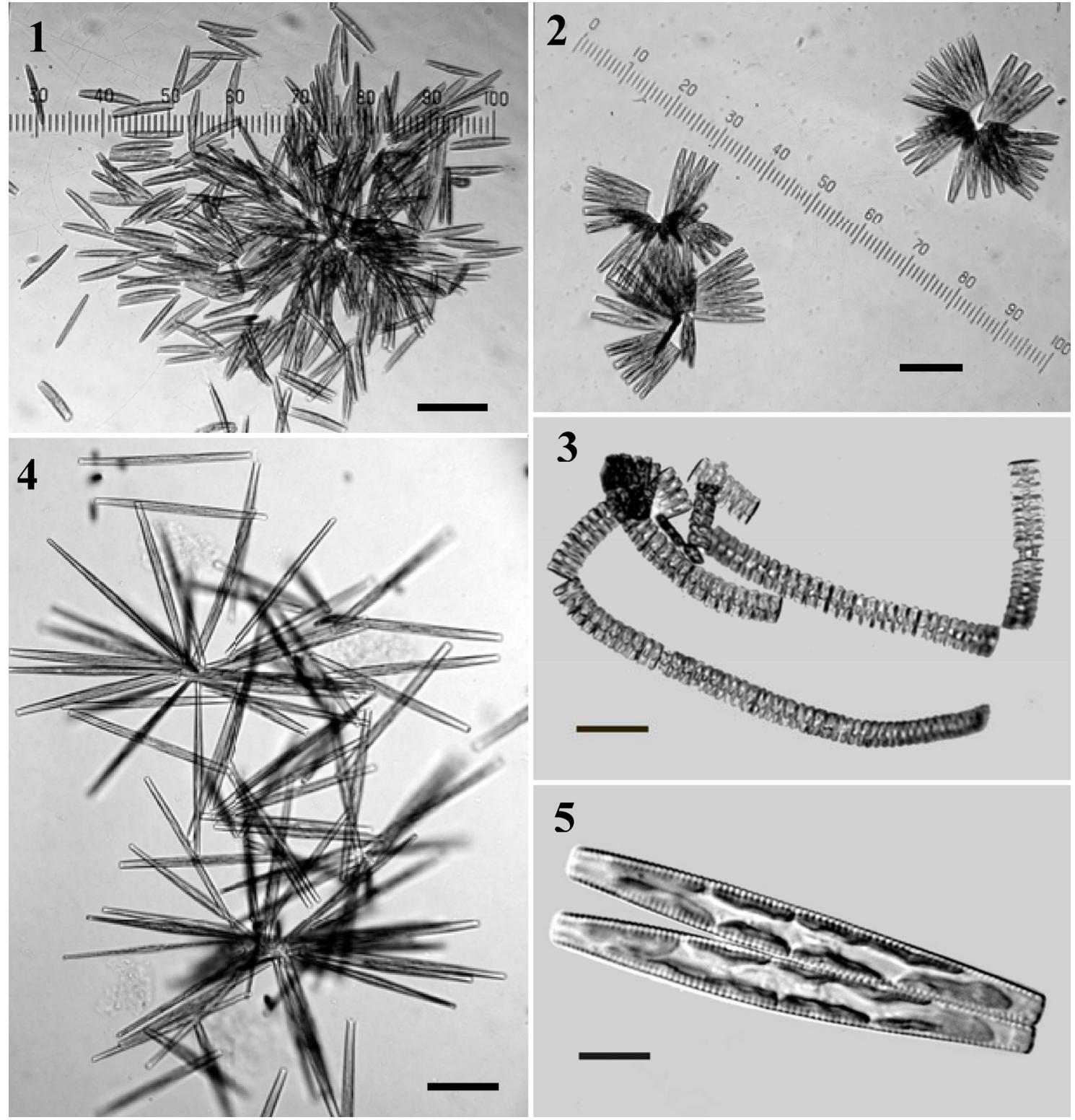

Figs 1-5. Tabularia fasciculata colonies of living cells, light microscopy (LM): (1) usual form of a colony of rapidly dividing cells; (2) infrequent fan-shape colonies; (3) ribbon-like colonies of small-size cells; (4) colonies of new post-sexual cells; (5) cells with eight chloroplasts. Scale bar $20 \mu \mathrm{m}$ (Fig. 5), $50 \mu \mathrm{m}$ (Figs 1-4).

cell size. Gametes in this auxosporulation were spherical and mobile; in all aspects of morphology and behavior they were similar to male gametes seen in heterothallic pairs (see below). We did not observe homothallic gamete fusion, in contrast to gamete fusion in interclonal crosses. Intraclonal reproduction was not abundant compared to the interclonal type, and only a few clones auxosporulated in monoclonal cultures.

Heterothallic (interclonal) reproduction: This mode of reproduction was first recorded in the mixture of clones T0206-A and T0206-G on the third day after inoculation. These clones were then used as a control pair. Mean cell lengths of parental clones in gametangial pairs were $63.7 \pm 0.9(\mathrm{n}=4)$ and $88.0 \pm 1.04(\mathrm{n}=4)$ $\mu \mathrm{m}$, respectively. Sexually compatible clones T0208- $\mathrm{X}$ and T0206-M were also used as an additional control pair. Neither clone in the last pair was able to reproduce intraclonally.

In clusters of mating cells (mated clones listed in Supplementary Table S1) we observed gametes of two types. Spherical gametes (which we designated as "male") were free of parent frustules and suspended in water (Fig. 21). Bell-shaped gametes (which we designated as "female", Fig. 22) were attached to parental valves. In the present paper we use terms "male" and 


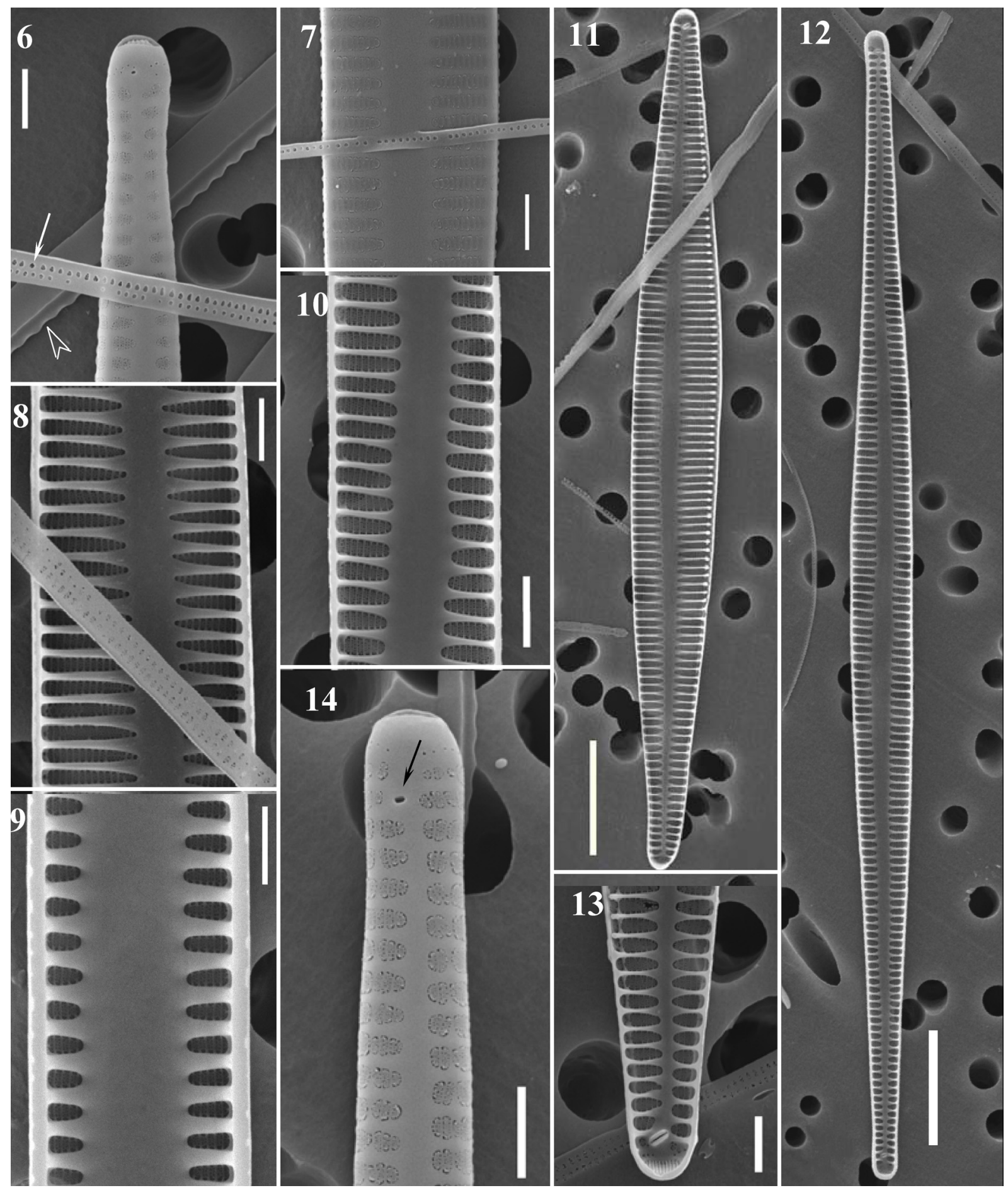

Figs 6-14. Tabularia fasciculata, scanning electron microscopy (SEM): (6) clone T0206-E, external view of the apex of one valve, note ocellulimbus and opening of rimoportula. Valvocopula is finely crenulated at one margin (arrowhead) and has no areolae; a copula (the order is unknown) may have two rows of areolae (arrow); note slight constriction at the cell apex. (7) a typical external view of stria areolae in clone T0206-H, a pleura with one row of areolae. (8) clone T0206-R, even among the cells of the same clone, the width of sternum may vary considerably (compare with Fig. 9). (9) clone T0206-R, note relatively broad sternum and striae areolae with cross-bars. (10) clone T0206-F, internal view of striae each with two large areolae with cribra and thin cross-bars. (11) clone T0206-Q, a valve with one rimoportulae, internal view. (12) a typical valve outline represented here by clone T0206-F, a valve with two rimoportula, internal view. (13) clone T0206-Q, internal view of the valve apex, note oval ending of rimoportula. (14) clone T0206-F, external view of the valve, external opening of rimoportula indicated by arrow; note obtuse shape of the valve apex. Scale bar $2 \mu \mathrm{m}$ (Figs 6-10, 13-14), $10 \mu \mathrm{m}(11,12)$. 


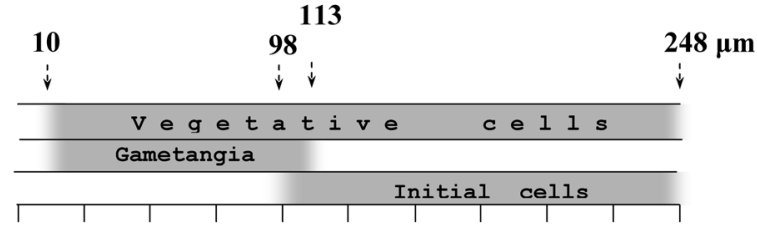

50

$100 \%$

Fig. 15. Diagram showing principal stages in the life cycle of Tabularia fasciculata. The numbers indicate minimal and maximal sizes of cells at the appropriate stages of the life cycle ('cardinal points'). To produce the diagram nearly 1500 cells of the species were measured, including 228 gametangial and 422 initial cells; and 148 pairwise interbred combinations of clones examined. Arrows indicate upper and lower borders corresponding to the size ranges of initial and gametangial cells.

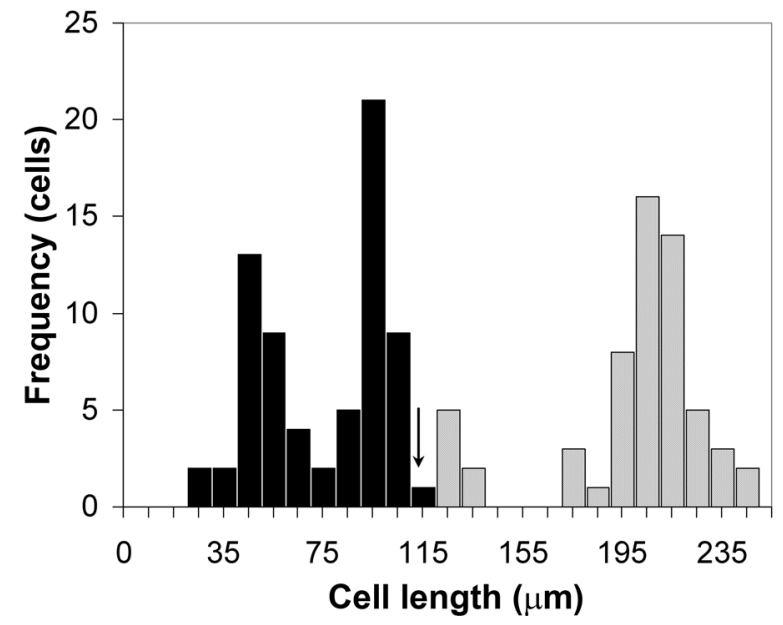

Fig. 16. Frequency distribution of the apical length of small cells $(n=68$, black) and initial cells resulted from sexual reproduction $(\mathrm{n}=59$, shading) in a local population of Tabularia fasciculata on a thallus of disintegrating Porphyra umbilicalis. The upper cell-size limit for sexualization is indicated by an arrow.

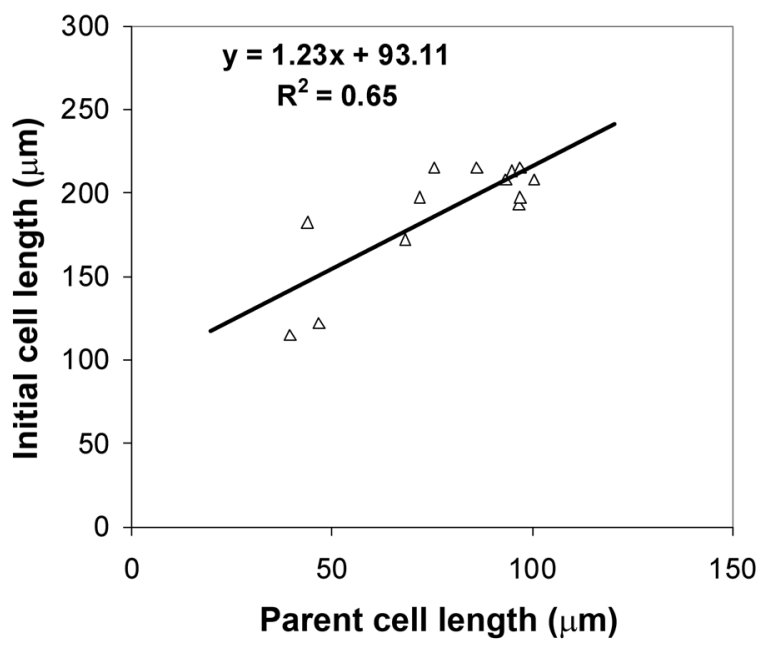

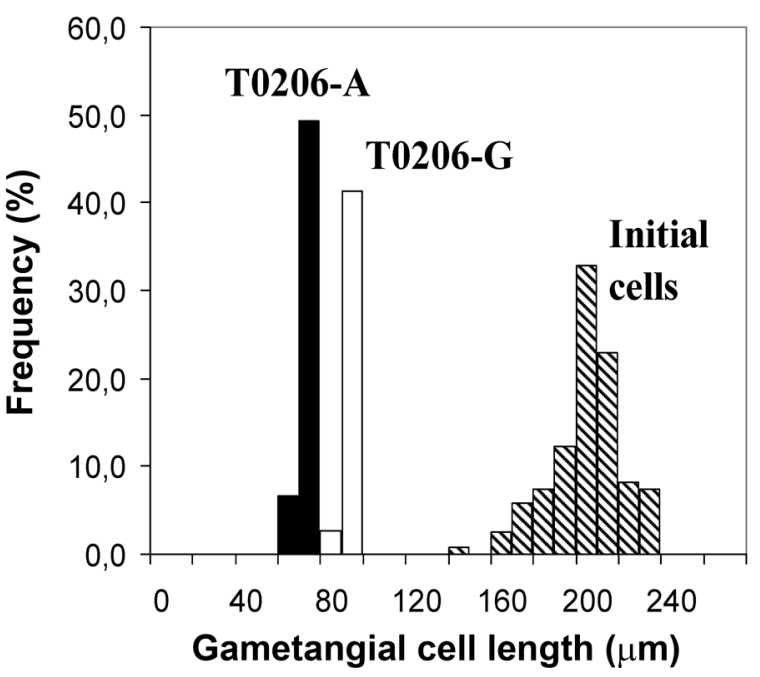

Fig. 18. Frequency distribution of the length of gametangia (n $=75)$ and of initial cells $(n=110)$ in two mating experiments with T0206-A and T0206-G clones on 7 and 14 March 2006. Frequency was calculated separately for parent and initial cells.

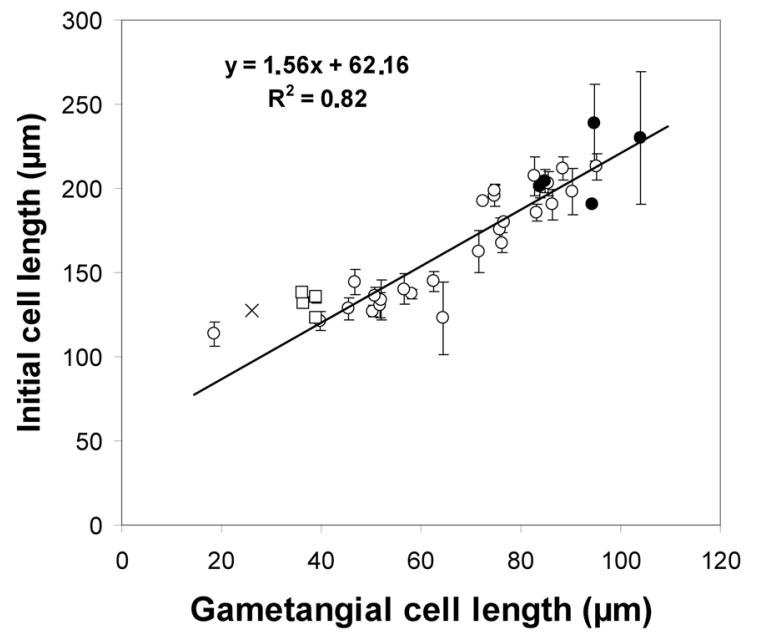

Fig. 19. Relationship between gametangial and initial cell lengths in Tabularia fasciculata, reproducing in culture. Canadian and Ukrainian clones are indicated by circles and squares accordingly; interclonal (open circles, $\mathrm{n}=25$ and open squares, $\mathrm{n}=4$ ) and intraclonal (solid circles, $\mathrm{n}=5$ ) progeny are plotted together. Sloping cross indicates results of allopatric mating. Gametangial cell length was calculated as the average of mean cell sizes in a pair of clones; initial cell length was calculated as the average of initial cell lengths in the mixture of parental clones. Regression line was calculated solely for Canadian clones.

Fig. 17. Relationship between length of gametangia and initial cells in an interbreeding local Canadian population of Tabularia fasciculata. Parent cell length was calculated as the average of lengths of frustules in a gametangial pair; the initial cell lengths were also averaged. 

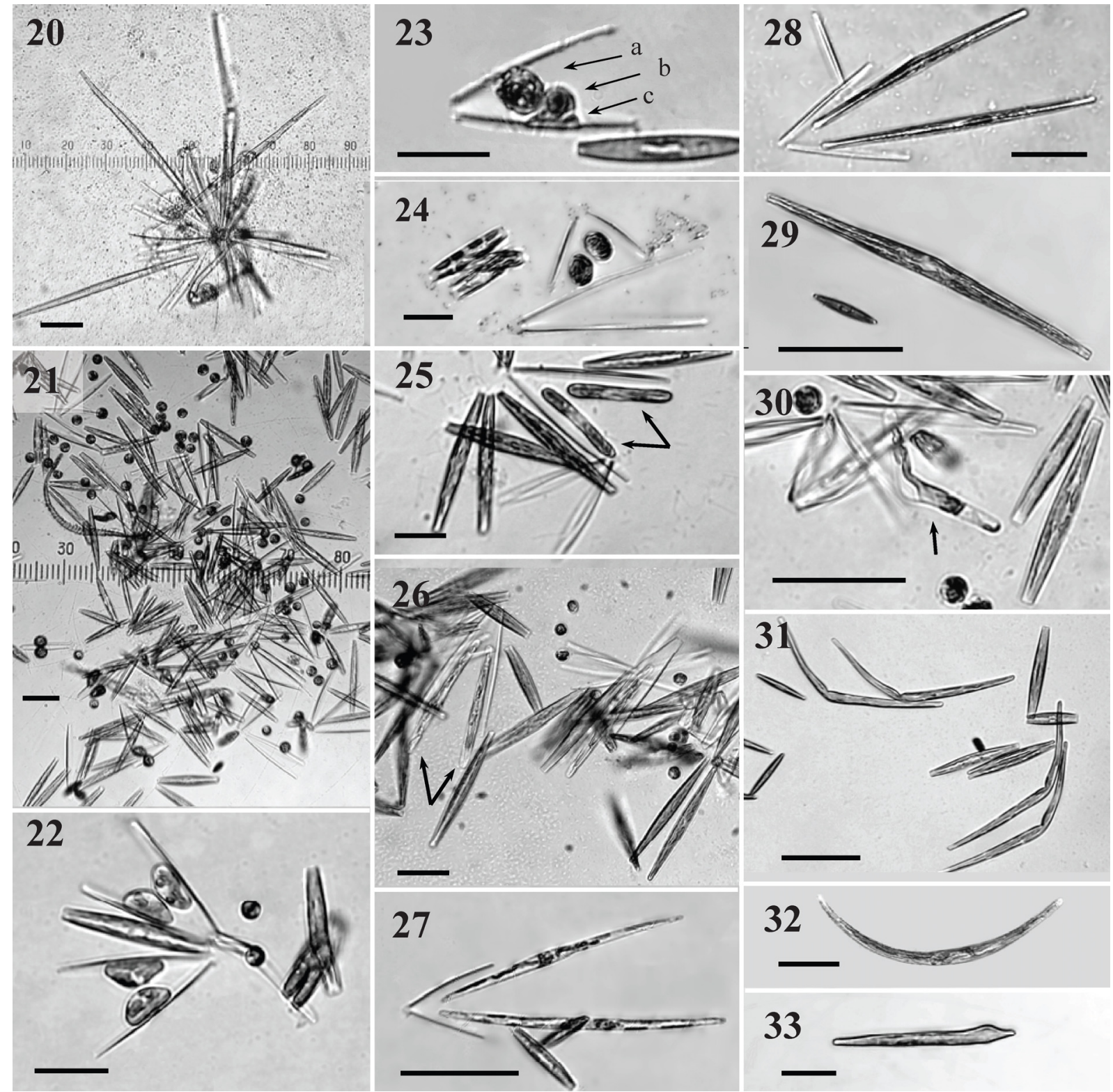

Figs 20-33. Tabularia fasciculata, sexual reproduction and aberrant cells, LM: (20) initial cells produced in the clonal culture T0208-AS, assumed to be resulted from intraclonal mating in this cluster of cells; note abundant bacterial flora that prevented further growth of the alga. (21) mass gametogenesis in the mixture of sexually compatible clones T 0206-A and T 0206-G, note predominance of spherical male gametes. (22) four female gametes (on the left) in two gametangia are typically bell-shaped and associated with mother frustules, while male gametes (on the right) are spherical and free floating. (23) a recently arisen zygote (a) is almost spherical and attached to maternal theca; male (b) and female (c) gametes appear just before plasmogamy. (24) two ellipsoidal zygotes at the onset of the bipolar expansion lying between open and empty maternal theca; an open and empty frustule of paternal gametangium just below. (25) pair of young auxospores (arrows) associated with maternal thecae (above); note open and empty male gametangium below. (26) two growing auxospores (arrows) and several free male gametes in proximity of open and empty gametangial thecae. (27) auxospores during expansion lie more or less parallel to each other and to maternal valves. (28) a pair of initial cells inside mature auxospores in typical position between open and empty parental theca. (29) the first mitotic division of one initial cell (above) disassociated from maternal theca; note great difference of the cell size in relation to one of the cells of the parental clone (below). (30) deformed auxospore (arrow) gives rise to an initial cell which can divide and maintain aberrant morphology in viable vegetative cells. (31) deformed descendants produced by deformed initial cells. (32) an example of a more common lunate aberrant form of post-initial cells. (33) another example of cell deformity likely due to the rapid cell reduction. Scale bar $20 \mu \mathrm{m}$ (Figs 22-26, 33), $50 \mu \mathrm{m}(20,21,27-32)$. 
Table 2. Sex and reproductive behavior of F1 progeny resulted from mating of male T 0206-P and female T 0214-AH clones of Tabularia fasciculata.

\begin{tabular}{lccccccc}
\hline $\begin{array}{l}\text { Name of F1 } \\
\text { generation clone }\end{array}$ & & T(P.AH)-A & T(P.AH)-Ba & T(P.AH)-E & T(P.AH)-C & T(P.AH)-D & T(P.AH)-G \\
& sex & F & F & F & M & M & M \\
\hline T(P.AH)-A & F & & & & & & \\
T(P.AH)-Ba & F & 0 & & & & & \\
T(P.AH)-E & F & nd & nd & & & & \\
T(P.AH)-C & M & + & nd & 0 & & \\
T(P.AH)-D & M & + & + & + & 0 & & \\
T(P.AH)-G & M & + & + & + & 0 & nd & \\
\hline
\end{tabular}

Notes: $(F)$ female clone; $(M)$ male clone; $(+)$ registered ability to interbreed; $(0)$ reproduction was not detected; (nd) no data.

Table 3. Sexual compatibility of interpopulation F1 progeny (C.T1) resulted from mating of Ukrainian clone T 0206-C_Ukr and Canadian clone T 0206-T1 with F1 Canadian progeny (P.AH).

\begin{tabular}{lccc}
\hline \multirow{2}{*}{ Name of F1 generation clone } & & $\mathrm{T}(\mathrm{P} . \mathrm{AH})-\mathrm{D}$ & $\mathrm{T}(\mathrm{P} . \mathrm{AH})-\mathrm{E}$ \\
\cline { 2 - 4 } & $\mathrm{sex}$ & $\mathrm{M}$ & $\mathrm{F}$ \\
\hline T(P.AH)-D & $\mathrm{M}$ & 0 & 0 \\
T(P.AH)-E & $\mathrm{F}$ & 3 & 0 \\
T(C.T1) 0206-A & $\mathrm{F}$ & 3 & 0 \\
T(C.T1) 0214-A & $\mathrm{F}$ & 3 & nd \\
T(C.T1) 0602-B & F & 2 & 2 \\
T(C.T1) 1211-D & M & 0 & 0 \\
T(C.T1) 1211-E & F & 2 & 2 \\
T(C.T1) 1211-B & M & 0 & 2 \\
T(C.T1) 1224-D & M & 0 & 0 \\
T(C.T1) 1224-E & F & 2 & \\
\hline
\end{tabular}

Notes: weak (1), moderate (2), or abundant (3) sexual reproduction was recorded; 0, sexual reproduction was not detected in the mixture; nd, mating was not fulfilled; F, female clones; $\mathrm{M}$, male clones.

"female" instead of "mating type +" or "mating type -", because we presume that behavioral and morphological divergence coincides not only to cross compatibility, but also to diplogenotypic mode of inheritance of sex determinants, even if chromosomes carrying these determinants are morphologically indistinguishable. Female gametes were not observed to lose contact with gametangial frustules. Gametangia bearing male and female gametes were sometimes positioned close to each other, but more frequently were separated by a distance that did not allow direct contact of gametangia of different mating types.
We did not count them, but it seemed that male gametes were more abundant than female ones in all crossing mixtures (Fig. 21).

Male gametes were mobile (although not all of them at all times) and moved vertically and horizontally in the field of view in an apparently random fashion while spinning around their axis (see Supplementary Videos). This type of gamete mobility has not been previously demonstrated in diatoms. Within one minute, a male gamete could move up to approximately ten times its diameter, but the actual path length was longer due to frequent changes in direction (Fig. 34). 


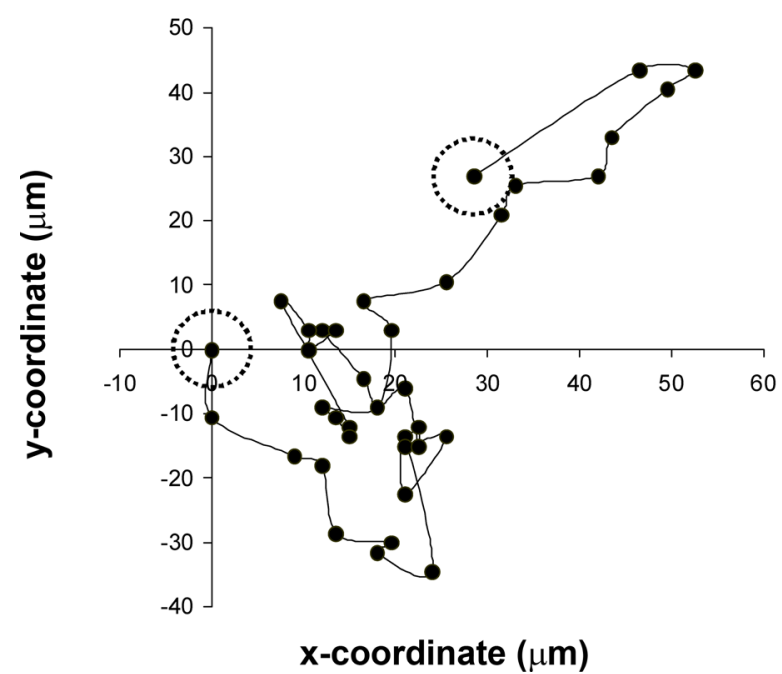

Fig. 34. Diagrammatic representation of the path of one male gamete over 3 minutes; shown here as $\mathrm{x}-\mathrm{y}$ coordinates traced from a real time video recording. Solid circles represent the location of the gamete centre every $4.7 \mathrm{sec}$; rings of small dots correspond to actual gamete size at start and finish positions.

Gamete mobility lasted from a few seconds to a few minutes, starting and ceasing unpredictably and alternating with periods (few minutes) of rest. Gamete spinning could accelerate or decelerate in the process of moving across the field of view. The mechanism of mobility is presently uncertain and un-resolvable when recorded in LM at $c$. x250 magnification. At any time only about one fifth to one fourth of gametes in the field of view were mobile. Active gametes usually ceased further movement upon contact with a gametangium bearing female gametes. We have now observed this phenomenon in multiple crosses involving a number of male and female clones, over 3 years of observations. Concurrent inspection of the mating dishes did not show the presence of pathogens and/or parasites.

Following physical contact and after a few minutes to a few hours, male and female gametes fused (Fig. 23) giving rise to spherical zygotes. Approximately two hours later zygotes started bipolar expansion of the auxospore stage (Figs 2426). In most cases, the apical axes of auxospores were more or less parallel to each other and to the valves of the maternal gametangia (Figs 25-28), but their attachment was not sufficiently firm to prevent otherorientations. Remnants of the primary zygote envelopes were not detectable in LM at the tips of swelling auxospores. Chloroplasts were evenly distributed along the expanding auxospore cell walls in the parietal layer of the cytoplasm
(Fig. 27). Inside the fully expanded auxospore, two thecae were deposited successively, giving rise to the initial cell (Fig. 28). Valves of the initial cell lay snugly against the auxospore envelopes. The initial cell began mitotic divisions within the auxospore envelope (Fig. 29).

Occasionally, aberrant auxospores were also observed (Fig. 30). The aberrant form did not prevent these auxospores from further development and deformities were passed onto the initial cells (Figs 31-33). Despite their atypical frustule architecture, such initial cells divided mitotically when inoculated into fresh medium (Fig. 31).

\section{Breeding behaviour}

Sexual compatibility of 42 clones was determined by pairwise crossing (Table 1); morphological and molecular characterisation of these and other clones is given in KACZMARSKA et al. (2009). Among sexually compatible clones, which were randomly derived from the natural local population, 21 were found to be male while 20 were female; the sex ratio in the population was thus 1:1 male:female. Additionally, clone T0208-AS could be regarded as male in view of its ability to reproduce intraclonally by producing spherical ("male") gametes, although successful direct mating with females was not observed in this case. Intraclonal reproduction was also detected in clones T0206-G, T0206-L and T0206-V when they were grown alone. These clones behaved as males when mated with female clones. Although more experiments are needed to confirm that female do not sexualize intraclonally, such behavior was not observed in wells inoculated with single female clones. Clone T0206-G reproduced intraclonally almost every time after re-inoculation into fresh medium, giving from 2-10 auxospores per Petri dish. Because of frequent intraclonal reproduction in this clone, it normally contained large vegetative cells produced in earlier intraclonal auxosporulations, in contrast to heterothallically reproducing clones. Among intraclonally reproducing clones of this species, frequency of homothallic reproduction in clone T0206-G was highest, but nonetheless much less abundant than heterothallic (interclonal) sexual reproduction. In the latter, hundreds of gametes (Fig. 21) and tens of auxospores were normally present in each mating Petri dish.

We tested mating compatibility between Canadian and Ukrainian clones. Six sibling F1 
progeny clones $\mathrm{T}$ (P.AH) resulting from mating of Canadian male T0206-P and female T0214-AH were found to be sexually compatible (Table 2) and their sex was determined. One of this female progeny, T(P.AH)-E and another Canadian female clone T0206-T1 (a sub-isolate of T0206-T ) were found sexually compatible with male clone T0206-C_Ukr derived from samples collected from the marine littoral near the Karadag biological station one year later. The allopatric progeny had species-typical cell morphology and the same cell sizes (Fig. 19, cross mark) that was characteristic of the Canadian and Ukrainian populations. Fourteen new progeny clones isolated from crossing of T0206-T1 and T0206-C_Ukr have been maintained in culture. These clones were found to be sexually compatible with F1 generations of Canadian clones (Table 3). Both male and female clones were revealed among interpopulation progeny.

\section{Discussion}

\section{Cell sizes and cardinal points in the life cycle}

In many diatoms, especially heavily silicified species, the frustule structure necessitates one mitotic progeny cell to maintain the parental frustule size while the other diminishes in size (Round et al. 1990). In T. fasciculata, during the lifespan of one individual progeny cell-line (one genotype), the apical cell length of the mitotically derived progeny may decrease by an order of magnitude, from 248 to $10 \mu \mathrm{m}$ (Fig. 15). Hence, assuming theoretically, for the purpose of comparison that in a population the mean cell apical length becomes shortened by one cingulum thickness per division (EDLUND \& STOERMER 1997), and further assuming that the mantle thickness shown above $(0.4 \mu \mathrm{m})$ is maintained through consecutive mitotic cycles, it would take about (248-10) / $0.4=595$ divisions for the largest progeny to diminish from the maximal to the minimal size. The longest life history of $T$. fasciculata would, thus, last for about 1.5 years, presupposing one division per day throughout the year.

Cells of some genotypes may have a shorter "lifespan" (used here to indicate number of mitotic divisions undergone) if they are sexualized at the upper limit of the sexually inducible size range, which in our clones falls at about $50 \%$ of the species-specific maximum size. This is in concordance with general tendency (DAVIDOvicH 2001). The individuals which would sexualize at the upper limit of the inducible size range would have the shortest "lifespan", (248-113) / $0.4=338$ divisions, which is a 1.8 times shorter than the maximal "lifespan". The smallest initial cells may fall within the sexually inducible size range or can reach the upper critical size after just several divisions; therefore their "lifespan" may be very short and mitotic progeny few in number. However, normally a wide range of sex-inducible size ensures that individual genotypes of this species may be reproductively inducible over a period of several growth seasons.

The strong relationship between the size of gametangial and initial cells (Figs 17, 19) is known also for other centric and pennate diatoms (e.g. Migita 1967; Roshchin 1973, 1994; Davidovich 2001; EdLUND \& BiXby 2001). In contrast, in a species closely related to our diatom, Tabularia tabulata, the size of initial cells was weakly dependent on the size of gametangia (RoshchIN 1994); see the same for other species in SCHMID (1995) and CHEPURNov et al. (2005).

On the other hand, even in the same pair of parent clones, T0206-A and T0206-G showing relatively narrow ranges of cell sizes (58-68 and $73-86 \mu \mathrm{m}$, respectively) and with low coefficients of variation (3.9 and 3.6\%), the size of resulting initial cells was more variable (coefficient of variation $8.2 \%)$ and spanned about a third (140$240 \mu \mathrm{m})$ of the specific size range (see Fig. 18). Therefore a number of initial cells emerging from a variety of parental cells of different sizes are needed before a species-specific range of cell size can be determined conclusively.

In the semi-natural population of $T$. fasciculata, two size classes were detected among sexualized individuals, and they gave rise to two size groups of initial cells (Fig. 16); the pattern also recovered in cultured clones (KACZMARSKA et al. 2009). The reason for the bimodal distribution of parent cell size in the semi-natural population is not entirely clear. For example, these diatoms could have represented two different cohorts of cells resulting from two different successful reproduction events that occurred at two different times, seen in other diatoms (Jewson 1992). However, in view of the mating results obtained, it is important to note that the dichotomy in parental and corresponding post-sexual cell populations cannot be regarded as two separate species, following the biological species concept. 


\section{Manner of sexual reproduction}

Almost all araphid diatom species examined to date are predominantly heterogamous (CHEPURNOV $\&$ MANN 2004). The gametes produced by our $T$. fasciculata clones of compatible sexes were also morphologically and behaviourally different, so it was possible to distinguish between "male" and "female" clones. Two gametes of a male gametangium lost contact with the frustule and dispersed to fuse with gametes of sexually compatible (female) gametangia. Female gametes normally did not leave the gametangial thecae. Thus, cis-anisogamous (sensu MANN 1982) gamete behaviour in T. fasciculata corresponds to the IA2 category of GeITLER's (1973) classification system. Further variation within this category depends on whether or not gametes rearrange during gametogenesis (type IA2a and IA2b respectively; Geitler 1973). However, T. fasciculata does not fit either of the two categories, because the male gametes seem to rearrange, whereas the female gametes do not (Fig. 22). This is similar to that observed in the raphid pennate Mastogloia smithii Thwaites ex W. Smith where gamete rearrangement occurred only in the gametangium, giving rise to active gametes (STICKLE 1986). In the araphid pennate Licmophora ehrenbergii (KüTZING) GRUNOw female gametes never rearranged, but gametes in male gametangia rearranged or not, depending on the relative position of the mating gametangia (Roshchin \& CHEPURNov 1994, 1999; Chepurnov \& MANN 2004). In contrast, in monoecious Achnanthes javanica f. subconstricta (Meister) Hustedt only the stationary gametes ("female") were reported to rearrange (Mizuno 1994). Therefore cis-anisogamy suggests but does not prove heterothally.

Cis-anisogamy occurs in both araphid and raphid diatoms. In contrast to araphid species, in raphid diatoms revealing cis-anisogamous behaviour the gametes are usually isomorphic, e.g. A. javanica f. subconstricta (Mizuno 1994), M. smithii (STICKLE 1986), or species from the genus Pseudo-nitzschia (DAVIDOvich \& Bates 1998). One exception from this pattern known thus far is Nitzschia longissima (BRÉB.) RALFS, where passive gametes sharply differ morphologically from active ones (KARSTEN 1899; RosHCHIN 1994; KACZMARSKA et al. 2007a).

Homothallic reproduction of $T$. fasciculata seems to be allogamous rather than autogamous, judging from twice the number of empty gametangia that were observed near auxospores. In a monoclonal culture reproducing homothallically, only spherical gametes corresponding in their morphology to "male" gametes were present. Unfortunately we could not observe the very moment of gamete syngamy, but drawing from evidence obtained for the close relative Tabularia tabulata (as Synedra tabulata) and another fragilarioid diatom, Fragilaria delicatissima (Roshchin, 1987, 1989, 1994) which were capable of reproducing intraclonally and isogamously, we tentatively postulate that in our species isogamous homothallic mating is probable.

\section{Mating system; dependence on mating behaviour}

Historically, Rhabdonema adriaticum KüTZING (von Sтоsch 1958) was the first diatom that revealed obvious dioecy, thereby challenging the general consensus of the time that all diatoms were homothallic (see also discussion in CHEPURNov et al. 2004). Later heterothally as a predominant or single mode of breeding was reported in other pennate diatoms, including araphid and raphid species (Roshchin 1987, 1989, 1994; RoshCHIN \& Chepurnov 1994; Davidovich \& Bates 1998; ChePuRnov \& MANN 2004). Heterothally should also be regarded as the principal mode of sexual auxosporulation in Tabularia fasciculata because weinvariably observed a greater number of gametes and initial cells in crosses of heterothallic pairs (Fig. 14) compared to homothallic reproduction, which was episodic and observed only in three male clones (Table 1).

Two other species of araphid diatoms are known to reproduce both hetero- and homothallically: Tabularia tabulata (RosHCHIN 1987, 1989, 1994) and Fragilaria delicatissima (Roshchin 1994) in addition to the raphid diatom Nitzschia longissima (DAvidovich et al. 2006). Reproductive behaviour of these species was interpreted by Roshchin as an alternation in generations of mode of sexuality from "monoecious" to "dioecious" (RoshCHIN 1987, 1989, 1994; RoshCHIN \& CHEPURNov 1999). Another explanation is also possible. The cisanisogamous raphid diatom Nitzschia longissima was recently re-examined and the sexual identity of about 70 clones established (DAVIDOVICH et al. 2006); among them 35 clones were male, and 21 of the male clones did reproduce intraclonally in the absence of females. No female clone showed intraclonal mating behaviour. The term facultative andromixis (DAVIDOVICH et al. 2006) was proposed 
for allogamous intraclonal sexual reproduction involving exclusively males. Clones of $T$. tabulata and $F$. delicatissima capable of intraclonal reproduction were also determined to be male and their homothallic reproduction was isogamous (Roshchin 1994). When applied to T. fasciculata, the notion of andromixis allowed us to predict the sex of intraclonally reproducing clones T0206-L and T0206-V as males. This was later confirmed by direct pairwise mating in combinations with female clones where typical heterothallic sexuality was observed between numerous parental gametangia. If we assume that isogamous intraclonal reproduction in $T$. fasciculata, as well as in T. tabulata, F. delicatissima, and $N$. longissima, which are predominantly heterothallic and cis-anisogamous, corresponds to the above mentioned phenomenon of andromixis, it would be unnecessary to relate two types of reproduction (hetero- and isogamy) to different subspecies (races, demes etc.) or to alternation of homo- and heterothallic generations.

Several other araphid diatom species are known where allogamous reproduction is accompanied by other modes of auxosporulation. For example, in addition to allogamy, an autogamy is known in Synedra ulna (GeitLer 1939) or haploid parthenogenesis in Licmophora abbreviata (CHEPURNOv IN RoshCHIN 1994) and $L$. ehrenbergii (RoshchIN \& CHEPURNov 1994). In $L$. abbreviata parthenogenetically derived haploid cells may persist in culture for some time and even induce gametogenesis in diploid cells of the opposite sex (CHEPURnov IN RoshCHIN 1994).

Why were only the male clones able to reproduce intraclonally? We hypothesize that this capacity is related to male gamete mobility. If this assumption is accepted, then one could further postulate that in trans-anisogamous heterothallic species clones of either mating type (both + and - ) would be able to reproduce intraclonally. This in fact has been shown to be the case in Nitzschia lanceolata W. SMith (Roshchin 1994), though the amoeboid nature of movement in that species differs from that observed in T. fasciculata.

The heterogametic nature of males should also be considered. At the same time, in view of scarcity of data obtained (just three male clones were proven to reproduce intraclonally) we cannot exclude the possibility that female clones of Tabularia fasciculata are also able to reproduce intraclonally. According to Fisher's Exact Test, the association between maleness and intraclonal auxosporulation was insignificant: female intraclonal auxosporulation might be revealed with further observations.

Facultative andromixis might carry an adaptive advantage as an auxiliary reproductive strategy to include more than one means of generating new genotypes and to possess the capacity to establish reproductively selfsupporting pioneering populations derived from a single male cell dispersed to distant geographic locations. It might also be postulated that intraclonal reproduction may afford a "last chance" for sexuality in unisexual cells close to the lower end of sex-inducible size. In either case, the role of heterothallic reproduction in T. fasciculata is principal and common, while intraclonal reproduction should be regarded as secondary and occasional. Other authors have postulated that intraclonal reproduction plays a secondary role not only because of lower frequency, but also because what is essentially inbreeding seems to have higher sensitivity to external factors and is restricted to a shorter period of the life cycle, as in T. tabulata (Roshchin 1994) and Achnanthes longipes AgARDH (CHEPURNov \& MANN 1997, 1999). This notion is not supported in T. fasciculata populations because we observed our clones reproducing intraclonally when cell size was close to the upper limit of the sexual size range (Figs 15, 19). Initial cells produced as a result of such intraclonal reproduction were viable and gave normally growing cultures, in contrast to species showing inbred depression in intraclonal progeny (CHEPURNov \& MANN 1999). Moreover, initial cells produced intraclonally were the largest of those observed in our study (Fig. 19), as was expected from the largest gametangia, and grew well in 4 years of culturing.

Finally, our discovery of male gamete mobility is unprecedented among non-centric diatoms and warrants separate, in depth investigation which is currently underway. We demonstrate the movement on provided supplementary material in hope to stimulate colleague interest in searching for other species with similar properties. We note, that the size of male gametes, presence of chloroplasts in these cells as well as direct observation of gamete formation in gametangial cells demonstrated that the mobile cells are indeed gametes and not colorless, flagellated putative pathogen or parasites, similar to those described as "flagellate" gametes in P. multiseries (SubBa Rao et al. 1991). We now 
have observed mobile male gametes among F1 male progeny and great many clones.

In summary, both our results and the literature cited indicate that diatom species may employ multiple and diverse reproductive strategies (at least in culture). This underscores a strong necessity to study the breeding system of diatom species as thoroughly as possible, including homothallic and heterothallic modes. Further, interbreeding of clones derived from Canadian waters and from the Black Sea indicates wide, pan-Atlantic distribution of sexually compatible populations of $T$. fasciculata, which is rather astounding considering the distance and differences in ecological conditions between these locations. While breeding barriers are absent in vitro, further work is needed to explore the nature of the genetic similarity and differentiation among these widely separated populations.

\section{Acknowledgements}

We thank C. Reid, M. Thaler and C. Jacob-Vaillancourt for laboratory assistance. Funding for this work was provided by the Natural Sciences and Engineering Research Council of Canada and Mount Allison fund for barcoding diatoms (IK).

\section{References}

Amato, A., Kooistra, W.H.C.F., Levialdi Ghiron, J.H., Mann, D.G., Pröschold, T. \& Montresor, M. (2007): Reproductive isolation among sympatric cryptic species in marine diatoms. - Protist 158: 193-207.

Andersen, R.A., Berges, J.A., Harrison, P.J. \& WatANABE, M.M. (2005): Recipes for freshwater and seawater media. In: ANDERSEN, R.A. (ed.): Algal culturing techniques. - pp. 429-538, Elsevier Academic Press.

Archibald, R.E.M. (1983): The diatoms of the Sundays and Great Fish Rivers in the Eastern Cape Province of South Africa. - Bibliotheca Diatomologica, 1. - 362 pp., J.Cramer, Vaduz.

Behnke, A., Friedl, T., Chepurnov, V.A. \& Mann, D.G. (2004): Reproductive compatibility and rDNA sequence analyses in the Sellaphora pupula species complex (Bacillariophyta). - Journal of Phycology 40: 193-208.

Chepurnov, V.A. \& Mann, D.G. (1997): Variation in the sexual behaviour of natural clones of Achnanthes longipes (Bacillariophyta). European Journal of Phycology 32: 147-154.

Chepurnov, V.A. \& Mann, D.G. (1999): Variation in the sexual behaviour of Achnanthes longipes (Bacillariophyta). II. Inbred monoecious lineages. - European Journal of Phycology 34:
$1-11$.

Chepurnov, V.A.\&Mann,D.G.(2004):Auxosporulation of Licmophora communis (Bacillariophyta) and a review of mating systems and sexual reproduction in araphid pennate diatoms. Phycological Research 52: 1-12.

Chepurnov, V.A., Mann, D.G., Sabbe, K. \& Vyverman, W. (2004): Experimental studies on sexual reproduction in diatoms. - International Review of Cytology 237: 91-154.

Chepurnov, V.A., Mann, D.G., Sabbe, K., Vannerum, K., Casteleyn, G., Verleyen, E., Peperzak, L. \& Vyverman, W. (2005): Sexual reproduction, mating system, chloroplast dynamics and abrupt cell size reduction in Pseudo-nitzschia pungens from the North Sea (Bacillariophyta). - European Journal of Phycology 40: 379-395.

Davidovich, N.A. (2001): Species specific sizes and size range of sexual reproduction in diatoms. - In: Economou-Amilli, A. (ed.): Proceedings of the 16th International Diatom Symposium. pp.191-196, University of Athens, Athens.

Davidovich, N.A. \& Bates, S.S. (1998): Sexual reproduction in the pennate diatoms Pseudonitzschia multiseries and P. pseudodelicatissima (Bacillariophyceae). - Journal of Phycology 34: 126-137.

Davidovich, N.A., Kaczmarska, I. \& Ehrman, J.M. (2006): The sexual structure of a natural population of the diatom Nitzschia longissima (Bréb.) Ralfs - In: Witkowski, A. (ed.): Proceedings of the 18th International Diatom Symposium. - pp. 27-40, Biopress Limited, Bristol.

EdLund, M.B. \& BIXBY, R.J. (2001): Intra- and interspecific differences in gametangial and initial cell size in diatoms. In: ECONOMOU-AMILLI, A. (ed.): Proceedings of the 16th International Diatom Symposium. - pp. 169-190, University of Athens, Athens.

EdLund, M.B. \& Stoermer, E.F. (1997): Ecological, evolutionary, and systematic significance of diatom life histories. - Journal of Phycology 33: 897-918.

Evans, K.M., Wortley, A.H. \& Mann, D.G. (2007): An assessment of potential diatom "barcode" genes (cox1, rbcL, 18S and ITS rDNA) and their effectiveness in determining relationships in Sellaphora (Bacillariophyta). - Protist 158: 349-364.

Geitler, L. (1932): Der Formwechsel der pennaten Diatomeen (Kieselalgen). - Archiv für Protistenkunde 78: 1-226.

Geitler, L. (1935): Reproduction and life history in diatoms. - Botanical Review 1: 149-161.

Geitler, L. (1939): Die Auxosporenbildung von Synedra ulna. - Berichte der Deutschen Botanischen Gesellschaft 57: 432-436. 
Geitler, L. (1973): Auxosporenbildung und Systematik bei pennaten Diatomeen und die Cytologie von Cocconeis-Sippen. - Österreichische Botanische Zeitschrift 122: 299-321.

Jewson, D.H. (1992): Size reduction, reproductive strategy and the life cycle of a centric diatom.Philosophical Transaction of the Royal Society of London B. 335: 191-213.

Kaczmarska, I., Davidovich, N.A. \& Ehrman, J.M. (2007a): Sex cells and reproduction in the diatom Nitzschia longissima (Bacillariophyta): discovery of siliceous scales in gamete cell walls and novel elements of the perizonium. Phycologia 46: 726-737.

Kaczmarska, I., Ehrman, J.M., Moniz, M.B.J. \& Davidovich, N.A. (2009): Phenotypic and genetic structure of interbreeding populations of the diatom Tabularia fasciculata (Bacillariophyta). - Phycologia 3: 48 (5): 391-403.

Kaczmarska, I., Martin, J.L., LeGresley, M.M. \& EHRMAN, J. (2005): Diversity of the diatom genus Pseudo-nitzschia Peragallo in the Quoddy Region of the Bay of Fundy, Canada. - Harmful Algae 4: 1-19.

Kaczmarska, I., Reid, C., Martin, J.L. \& Moniz, M.B.J. (2008): Morphological, biological, and molecular characteristics of the diatom Pseudonitzschia delicatissima from the Canadian Maritimes. - Botany 86: 763-772.

Kaczmarska, I., Reid, C. \& Moniz, M. (2007b): Diatom taxonomy: morphology, molecules and barcodes. In: KusBer, W.H. \& JAHN, R. (eds.): Proceedings of the 1st Central-European Diatom Meeting. - pp. 69-72, Berlin-Dahlem.

Karsten, G. (1899): Die Diatomeen der Kieler Bucht. - Wissenschaftliche Meeresuntersuchungen (Kiel), new series 4: 17-207.

Kooistra, W.H.C.F., Forlani, G. \& De Stefano, M. (2009) Adaptations of araphid pennate diatoms to a planktonic existence. - Marine Ecology 30: $1-15$.

Lundholm, N., Moestrup, Ø., Hasle, G.R. \& HoefEmden, K. (2003): A study of the Pseudonitzschia pseudodelicatissima/cuspidata complex (Bacillariophyceae): what is $P$. pseudodelicatissima? - Journal of Phycology 39: 797-813.

Lundholm, N., Moestrup, Ø., Kotaki, Y., Hoef-Emden, K., Scholin, C. \& Miller, P. (2006): Inter-and intraspecific variation of the Pseudo-nitzschia delicatissima complex (Bacillariophyceae) illustrated by rRNA probes, morphological data and phylogenetic analyses. - Journal of Phycology 42: 464-481.

ManN, D.G. (1982): Auxospore formation in Licmophora (Bacillariophyta). - Plant Systematics and Evolution 139: 289-294.

Mann, D.G., Chepurnov, V.A. \& Droop, S.J.M.
(1999): Sexuality, incompatibility, size variation, and preferential polyandry in natural populations and clones of Sellaphora pupula (Bacillariophyceae). - Journal of Phycology 35: 152-170.

Mann, D.G., Chepurnov, V.A. \& Idei, M. (2003): Mating system, sexual reproduction, and auxosporulation in the anomalous raphid diatom Eunotia (Bacillariophyta). - Journal of Phycology 39: 1067-1084.

Manhart, J.R., Fryxell, G.A., Villas, M.C. \& Segura, L.Y. (1995): Pseudo-nitzschia pungens and P. multiseries (Bacillariophyceae): nuclear ribosomal DNAs and species differences. -Journal of Phycology 31: 421-427.

Migita, S. (1967): Morphological and ecological studies on sexual reproduction of marine centric diatoms. - Informational Bulletin on Planktology in Japan 14: 13-22. (In Japanese).

Mizuno, M. (1994): Sexual reproduction and auxospore formation in Achnanthes javanica $\mathrm{f}$. subconstricta. - Diatom Research 9: 133-141.

Moniz, M.B.J. \& Kaczmarska, I. (2009): Barcoding diatoms: is there a good marker? - Molecular Ecology Resources 9: 1-10.

Morales, E.A. (2003): Fragilaria pennsylvanica, a new diatom (Bacillariophyceae) species from North America, with comments on the taxonomy of the genus Synedra Ehrenberg. - In: Proceedings of the Academy of Natural Sciences of Philadelphia. - 153: 155-166.

Roshchin, A.M. (1973): O haraktere ukrupneniya kletok Coscinodiscus granii Gough. - Biologicheskie nauki 5: 78-81.

Roshchin, A.M. (1987): Diatomovaya vodorosl' s odnodomnym i dvudomnym vosproizvedeniem. - Zhurnal Obshchej Biologii 48: 771-783.

Roshchin, A.M. (1989): Proyavlenie intsukhta u diatomovoj vodorosli Synedra tabulata. Zhurnal Obshchej Biologii 50: 412-416.

Roshchin, A.M. (1994): Zhiznennye Tsikly Diatomovykh Vodoroslej. - 170 pp., Naukova Dumka, Kiev.

Roshchin, A.M. \& Chepurnov, V.A. (1994):Allogamnyj polovoj protsess i gaploidnyj partenogenez u dvudomnoy vodorosli Licmophora ehrenbergii (KÜTZ.) GRUN. (Bacillariophyta). - Algologia 4: 3-10.

Roshchin, A.M. \& Chepurnov, V.A. (1999): Dioecy and monoecy in the pennate diatoms (with reference to the centric taxa). - In: Mayama, M., Idei, M., \& Koizumi, I. (eds.): Proceedings of the 14th International Diatom Symposium. - pp. 241261, Koeltz Scientific Books, Koenigstein.

Round, F.E., Crawford, R.M. \& Mann, D.G. (1990): The Diatoms. Biology and morphology of the genera. - 747 pp., Cambridge University Press, Cambridge. 
SARno, D., Kooistra, W.H.C.F., Medlin, L.K., Percopo, I.\& Zingone, A. (2005): Diversity in the genus Skeletonema (Bacillariophyceae).II. An assessment of the taxonomy of $S$. costatumlike species with the description of four new species. - Journal of Phycology 41: 151-176.

Schmid, A.-M.M. (1995): Sexual reproduction in Coscinodiscus granii Gough in culture: a preliminary report. - In: MARINO, D. \& Montresor, M. (eds.), Proceedings of the 13th International Diatom Symposium. - pp. 139159, Biopress, Bristol.

Snoeis, P. (1992): Studies in the Tabularia fasciculata complex. - Diatom Research 7: 313-344.

StickLe, A. J. (1986): Mastogloia smithii has a method of sexual reproduction hitherto unknown in raphid diatoms. - Diatom Research 1: 271282.

Stoermer, E.F. \& Andresen, N.A. (2006): Atypical Tabularia in costal Lake Erie, USA. - In: Ognjanova-Rumenova, N. \& Manoylov, K. (eds): Fossil and recent phycological studies. - pp. 351-361, Pensoft Publishers, Sofia-
Moscow.

Stosch, H.A. von (1958): Kann die oogame Araphidee Rhabdonema adriaticum als Bindeglied zwischen den beiden grossen Diatomeengruppen angesehen werden? - Berichte der Deutschen Botanischen Gesellschaft 71: 241-249.

Subba Rao, D.V., Partensky, F., Wohlgeschaffen, G. \& LI, W.K.W. (1991): Flow cytometry and microscopy of gametogenesis in Nitzschia pungens, a toxic, bloom-forming, marine diatom. - Journal of Phycology 27: 21-26.

Williams D.M. \& Round F.E. (1986): Revisions of the genus Synedra Ehrenb. - Diatom Research 1: 313-339.

(C) Czech Phycological Society

Received February 10, 2010

Accepted May 19, 2010

Supplementary material

the following supplementary material is available for this article:

Table S1. Table of mating of Tabularia fasciculata clones (modified according to Kaczmarska et al. 2009).

Video 1: Gamete movement

Video 2: Gamete movevemt

This material is available as part of the online article (http://fottea.czechphycology.cz/contents) 